\title{
Trichomycetes (Zygomycota) in the Digestive Tract of Arthropods in Amazonas, Brazil
}

\author{
Yamile B Alencar/ ${ }^{+}$, Claudia M Ríos-Velásquez*, Robert W Lichtwardt** , Neusa Hamada
}

Coordenação de Pesquisas em Entomologia, Instituto Nacional de Pesquisas da Amazônia, Caixa Postal 478, 69011-970 Manaus, AM, Brasil **Department of Ecology \& Evolutionary Biology, University of Kansas, Lawrence, KS, US *Centro de Pesquisas Leônidas e Maria Deane-Fiocruz, Manaus, AM, Brasil

Eight species of Harpellales and three species of Eccrinales (Zygomycota: Trichomycetes) were found associated with the digestive tract of arthropods from terrestrial and aquatic environments in the central Amazon region of Brazil. New species of Harpellales include: Harpella amazonica, Smittium brasiliense, Genistellospora tropicalis in Simuliidae larvae and Stachylina paucispora in Chironomidae larvae. Axenic cultures of S. brasiliense were obtained. Probable new species of Enterobryus (Eccrinales), Harpella, and Stachylina (Harpellales) are described but not named. Also reported are the previously known species of Eccrinales, Passalomyces compressus and Leidyomyces attenuatus in adult Coleoptera (Passalidae), and Smittium culisetae and Smittium aciculare (Harpellales) in Culicidae and Simuliidae larvae, respectively. Comments on the distribution of some of these fungi and their hosts in the Neotropics are provided.

Key words: Coleoptera - Diplopoda - Diptera - fungi - Trichomycetes

Trichomycetes (Zygomycota) are obligate symbionts that live in the digestive tract of various insects and other arthropods, attached without penetration to the linings of the gut (Lichtwardt 1986). The large variety of hosts includes terrestrial, marine and freshwater arthropods, most commonly Chironomidae, Culicidae, Simuliidae, Coleoptera, Plecoptera, and Ephemeroptera, as well as several kinds of Crustacea and Diplopoda (White et al. 2000).

The relationship of Trichomycetes to their hosts is generally commensalistic or pathogenic, and, in some cases, mutualistic depending on developmental and environmental conditions (López Lastra 1990, Lichtwardt 1996).

The class Trichomycetes consists of three orders: Harpellales, Asellariales, and Eccrinales, of which only Harpellales contain culturable species (Misra \& Lichtwardt 2000). Other authors have included a fourth order: Amoebidiales. Though protozoans (Benny \& O'Donnell 2000) and therefore not phylogenetically related to fungi, Amoebidiales have been traditionally included in the Trichomycetes (Lichtwardt 1986, 1996) because of their ecological similarities.

Little is known about Trichomycetes in South America (López Lastra 1990, Lichtwardt \& Arenas 1996, Misra 1998, Lichtwardt et al. 1999a, 2000), whereas they have been much better studied in the Nearctic (Lichtwardt 1986, Labeyrie et al. 1996, Lichtwardt et al. 2001).

This study received partial financial support from PPI 1-3070, 1-3630, and CNPq (AP-400028/99-9).

${ }^{+}$Corresponding author. Fax: +55-92-642.8909. E-mail: yamile@argo.com.br. The senior author received a doctoral fellowship from CNPq.

Received 28 March 2003

Accepted 1 July 2003
In this investigation we present a taxonomic study and information about the biogeography of Trichomycete fungi in the central Amazon. The taxonomic part includes descriptions of new species of Harpellales: Harpella amazonica, Smittium brasiliense, Genistellospora tropicalis, and Stachylina paucispora. Other species of Harpella, Stachylina, and Enterobryus (Eccrinales) are described but not named due to insufficient number of collected specimens. We also record previously known species, including Smittium culisetae Lichtwardt in mosquito larvae (Pereira et al. 2000), Smittium aciculare Lichtwardt in Simuliidae larvae, Passalomyces compressus (Thaxter) Lichtwardt, White, Cafaro \& Misra (1999b) and Leidyomyces attenuatus (Leidy) Lichtwardt, White, Cafaro \& Misra (1999b) in adult Coleoptera (Passalidae).

\section{MATERIALS AND METHODS}

This study was conducted in October 2000 in different localities within the municipalities of Manaus and Presidente Figueiredo, Amazonas (Fig. 1, Table).

Larvae of aquatic insects (Chironomidae, Culicidae, Simuliidae) were collected using forceps, pipettes, sieves, and nets, placed in containers and stored under refrigeration before being dissected in the laboratory. Coleoptera (Passalidae) and Diplopoda were dug from decomposing tree trunks or from ground litter. In the laboratory, the arthropods were dissected in distilled water with forceps and needles. The peritrophic membrane and hindgut were mounted on microscope slides in distilled water for detection of the presence of gut fungi. Measurements of fungal structures (thalli, holdfasts, spores) were done from slides of living material examined with phase-contrast microscopy and selectively photographed. The fungi were preserved on semipermanent slides in lactophenol-cotton blue and sealed with colorless fingernail polish.

Cultures were made according to methods described by Lichtwardt (1986). Hindguts with Harpellales were 


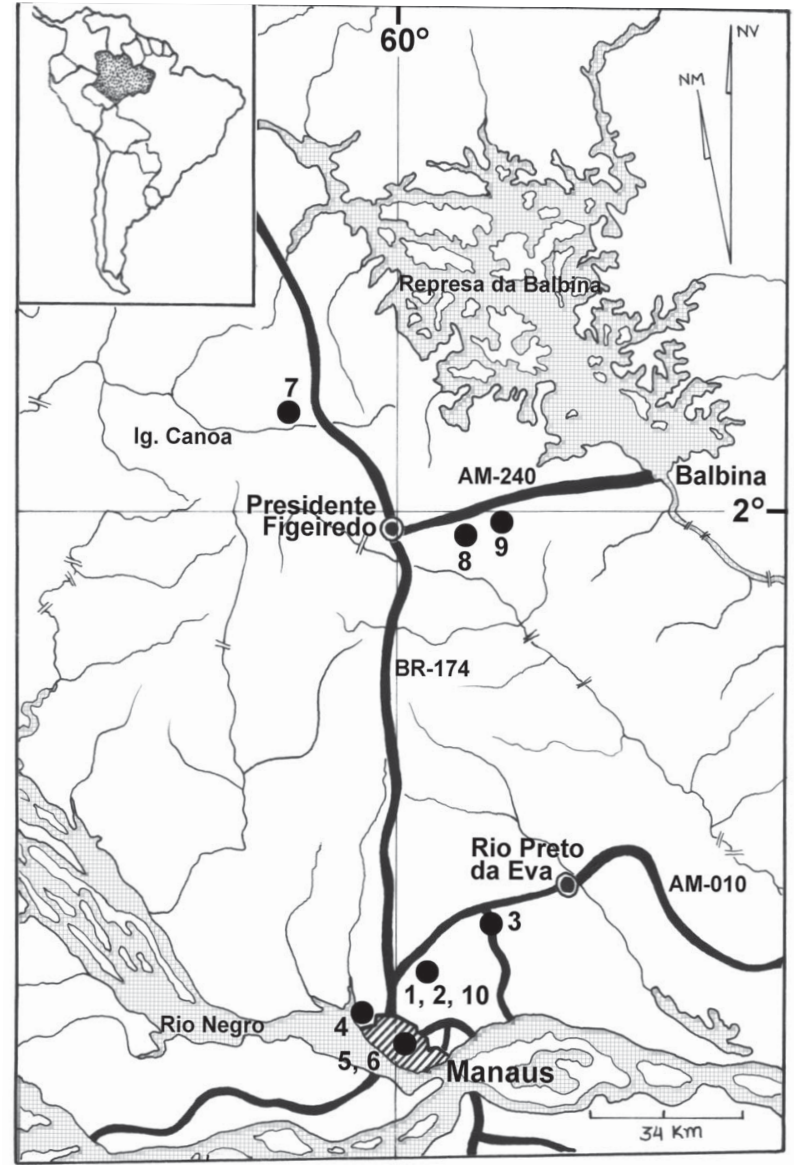

Fig. 1: collection sites in Manaus and Presidente Figueiredo counties, Amazonas, Brazil. Refer to Table for more specific data. washed in a penicillin-streptomycin antibiotic solution and plated on dilute brain-heart infusion agar (1/10 BHI) with a thin overlayer of distilled water. Successful isolates were transferred to slants of the same medium to which about $1 \mathrm{ml}$ of distilled water had been added.

Type specimens of new species consist of prepared slides or photographs, and are deposited in the Herbário do Instituto Nacional de Pesquisas da Amazônia (Inpa), Manaus, AM, Brazil.

\section{DESCRIPTION OF NEW SPECIES}

Genistellospora tropicalis, sp. nov Ríos-Velásquez, Alencar, Lichtwardt \& Hamada (Figs 2-6)

Branched thalli with a main axis 114-243 $\mu \mathrm{m}$ long from which lateral branches arise. Holdfast may be shaped like a horseshoe. Ovoid trichospores [20-27 x 3-(6)-8 $\mu \mathrm{m}$ ] without collar, each with about 6 fine appendages, produced in high numbers. Zygospores (50-60 x 8-10 $\mu \mathrm{m}$ ) attached medially and oriented parallel to the axis of the zygosporophore. Zygosporophores about 40-45 x 7-8 $\mu \mathrm{m}$. Supporting cell (below zygosporophore) with a straight or thumblike lateral extension. Frequently found in Simuliidae larvae and sometimes observed together with Harpella and Smittium in the same simuliid gut.

Diagnosis: thalli ramosi, axe primario 114-243 $\mu \mathrm{m}$ longo ex eo rami laterales orientes. Haustoria interdum hippocrepica. Trichosporae ovoideae [20-27 x 3-(6)-8 $\mu \mathrm{m}]$, collare carentes, abundantes. Zygosporae (50-60 x 8-10 $\mu \mathrm{m})$, medifixae, paralleliter ad axem zygophori dispositae. Zygosporophora ca. 40-45 x 7-8 $\mu \mathrm{m}$, cellula suffulta eorum extensione laterali polliciformi recta vel flexa praedita. In

TABLE

Trichomycete collection sites in Amazônia

\begin{tabular}{|c|c|c|c|}
\hline Site & Habitat & Date & Longitude/Latitude \\
\hline 1 & $\begin{array}{l}\text { HW AM010 km 24, Reserva Florestal Adolpho Ducke, Igarapé I, } \\
\text { Manaus county }\end{array}$ & $6-10-2000$ & $02^{\circ} 57^{\prime} \mathrm{S} ; 59^{\circ} 57^{\prime} \mathrm{W}$ \\
\hline 2 & $\begin{array}{l}\text { HW AM010, km 24, Reserva Florestal Adolpho Ducke, } \\
\text { Igarapé Barro Branco, Manaus county }\end{array}$ & $\begin{array}{l}10-10-2000 \\
14-10-2000\end{array}$ & $02^{\circ} 34^{\prime} \mathrm{S} ; 60^{\circ} 07^{\prime} \mathrm{W}$ \\
\hline 3 & $\begin{array}{l}\text { HW AM010 km 51, km } 4 \text { of ramal CIGS (Candiru stream tributary), } \\
\text { Manaus county }\end{array}$ & $14-10-2000$ & $02^{\circ} 45^{\prime} \mathrm{S} ; 59^{\circ} 51^{\prime} \mathrm{W}$ \\
\hline 4 & $\begin{array}{l}\text { HW AM010, km 11, Reserva Particular de Associação Brasil Soka Gakkai } \\
\text { Internacional, RPPN, Av. Desembarcador Anísio Jobim, Estrada do Aleixo, } \\
\text { Manaus county }\end{array}$ & $5-10-2000$ & $03^{\circ} 06^{\prime} \mathrm{S} ; 59^{\circ} 54^{\prime} \mathrm{W}$ \\
\hline 5 & $\begin{array}{l}\text { Bosque da Ciência, Paiol da Cultura, Inpa Campus, Av. André Araújo 2936, } \\
\text { Manaus county }\end{array}$ & $10-10-2000$ & $03^{\circ} 06^{\prime} \mathrm{S} ; 59^{\circ} 54^{\prime} \mathrm{W}$ \\
\hline 6 & Main Inpa campus, Av. André Araújo 2936, Petrópolis, Manaus county & $16-10-2000$ & $03^{\circ} 06^{\prime} \mathrm{S} ; 59^{\circ} 54^{\prime} \mathrm{W}$ \\
\hline 7 & $\begin{array}{l}\text { HW BR } 174 \text { km 134, Road to Comunidade Castanhal, Igarapé Canoas, } \\
\text { Presidente Figueiredo county }\end{array}$ & $11-10-2000$ & $01^{\circ} 46^{\prime} \mathrm{S} ; 60^{\circ} 28^{\prime} \mathrm{W}$ \\
\hline 8 & HW AM240 km 12, Cachoeira Santuário, Presidente Figueiredo county & $11-10-2000$ & $02^{\circ} 03^{\prime} \mathrm{S} ; 59^{\circ} 55^{\prime} \mathrm{W}$ \\
\hline 9 & $\begin{array}{l}\text { HW AM } 240 \text { km 20, Pousada Sossego da Pantera, Igarapé da Onça, } \\
\text { Presidente Figueiredo county }\end{array}$ & $11-10-2000$ & $02^{\circ} 02^{\prime} \mathrm{S} ; 59^{\circ} 50^{\prime} \mathrm{W}$ \\
\hline 10 & $\begin{array}{l}\text { HW AM010 km 24, Igarapé Acará, Reserva Florestal Adopho Ducke, } \\
\text { Manaus county }\end{array}$ & $6-10-2000$ & $02^{\circ} 57^{\prime} \mathrm{S} ; 59^{\circ} 57^{\prime} \mathrm{W}$ \\
\hline
\end{tabular}

HW: highway; BR: Federal highway; AM: Amazonas state highway 


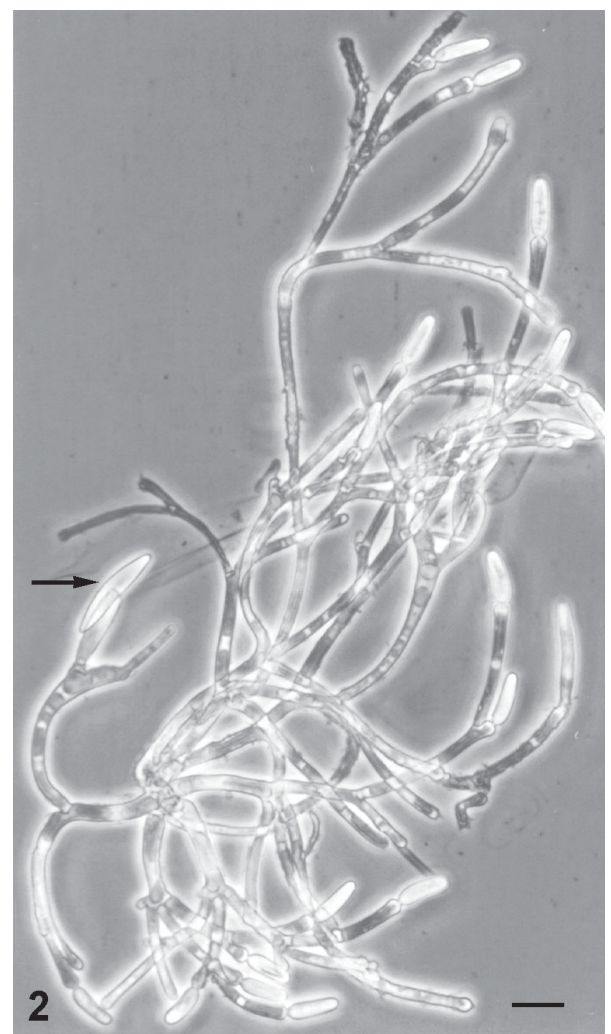

Fig. 2: Genistellospora tropicalis. Entire thallus removed from a Simuliidae larva hindgut bearing trichospores and one zygospore (arrow). Scale bar $=25 \mu \mathrm{m}$

proctodae larvarum Simuliidarum

Etymology: from the tropics

Holotype: microscope slide BR-8-1, from which photographs B19 and B20 were made (show thallus with attached trichospores, released trichospores and zygospores) prepared from a larva of Simulium goeldii Cerqueira \& Nunes de Mello (Diptera: Simuliidae) collected on 6-X-2000 from Igarapé I (Site 1, Table).

Paratype: Simulium ulyssesi (Py-Daniel \& Coscarón), S. goeldii and Simulium trombetense Hamada, Py-Daniel \& Adler larvae infected with $G$. tropicalis were found in streams at the Sites 2 and 8 (Table). Almost all specimens examined were infected with $G$. tropicalis, most of them with trichospores and a few with zygospores.

Four other species of Genistellospora are currently described: G. homothallica Lichtwardt 1972, G. nubila Lichtwardt 1997, G. guanacastensis Lichtwardt 1997 and G. tepidaria Lichtwardt 1997. G. homothallica appears to have a worldwide distribution, being found in US, England (Lichtwardt 1986), Chile (Lichtwardt \& Arenas 1996), Costa Rica (Lichtwardt 1997) and Argentina (Lichtwardt et al. 1999a). The other three species have only been found in Costa Rica (Lichtwardt 1997). Of the previously described species, G. tepidaria is the most similar to G. tropicalis, whose trichospores (21-31 x 9-11 $\mu \mathrm{m})$ are wider and zygospores $(58-70 \times 10-15 \mu \mathrm{m})$ are slightly longer and wider than those of G. tepidaria.

\author{
Harpella amazonica, sp.nov. \\ Ríos-Velásquez, Lichtwardt, Hamada \& Alencar \\ (Figs 7-9)
}

Narrow and short thalli, about 104-150 $\mu \mathrm{m}$ long by 3-4 $\mu \mathrm{m}$ diam. Base rounded with holdfast of less diameter than the thallus. Curved to almost coiled trichospores (33-52 x 3-4 $\mu \mathrm{m}$ ), with about 4 very fine appendages. Thalli producing very few trichospores (only 2 to 3 per thallus). Zygospores unknown. Attached to the peritrophic membrane of Simuliidae larvae (black fly).

Diagnosis: thalli angusti brevesque, ca. 104-150 $\mu \mathrm{m}$ longi, 3-4 $\mu \mathrm{m}$ diam., ad basem rotundati, haustoriis in diametro quam thallis minoribus. Trichosporae (33-52 x 3-4 $\mu \mathrm{m})$, curvae vel subspirales, 2-3 per thallum. Zygosporae ignotae. Ad membranam peritrophicam larvarum Simuliidarum affixi.

Etymology: from the Amazonian region.

Holotype: microscope slide BR-7-1, from which photographs A3, A4 and A5 were made (show thallus, holdfast and attached and released trichospores) prepared from a larva of Simulium rorotaense Floch \& Abonnenc (Diptera: Simuliidae) collected on 11-X-2000 from Igarapé da Onça (Site 9, Table).

Paratype: S. goeldii larvae infected with $H$. amazonica were found in streams at the Sites 1 and 2 (Table). Almost all specimens examined were infected with $H$. amazonica, but few showed trichospores.

Four other species of Harpella are currently described: H. melusinae L. Léger \& Duboscq, 1929 found in many regions of the world (Australia, New Zealand, Japan, North America, Europe and many regions at Northern Hemisphere); H. leptosa Moss \& Lichtwardt, 1980 known only from northwest Montana and Utah, US; H. meridianalis Lichtwardt \& Arenas, 1996 found in Chile and Argentina and H. tica Lichtwardt, 1997 found in Costa Rica (Lichtwardt 1997), Puerto Rico (White et al. 2000), and Argentina (Lichtwardt et al. 2000).

$H$. amazonica has a shape similar to $H$. melusinae, $H$. leptosa and $H$. meridianalis being close to $H$. meridianalis, but thalli and trichospores of $H$. amazonica are shorter and narrower. Trichospores are different from those of $H$. tica, which are sigmoid.

Smittium brasiliense, sp. nov.

Alencar, Lichtwardt, Ríos-Velásquez \& Hamada (Figs 10-21)

Mature thalli often growing in large tufts or clumps, verticillate branching. Holdfast horseshoe shaped. Longellipsoidal trichospores (13-)18(-26) x 1.6(-3) $\mu \mathrm{m}$ with a very short collar and one appendage. Biconical zygospores almost cylindrical (32-)40(-43) x 4-5 $\mu \mathrm{m}$ with a collar near one end and a single appendage. In the hindgut of Simuliidae (black fly) larvae.

Diagnosis: thalli maturi saepe in fasciculos vel caespites magnos crescentes, in verticillos ramificantes. Haustoria hippocrepica. Trichosporae longi-ellipsoideae, (13)18(-26) x 1.6(-3) $\mu \mathrm{m}$, collare brevissimo atque appendiculo unico praeditae. Zygosporae biconicae, subcylindricae, (32)40 (-43) x 4-5 $\mu \mathrm{m}$, collare prope extremum alterum atque appendiculo unico praeditae. In proctodaeo larvarum Simuliidarum. 

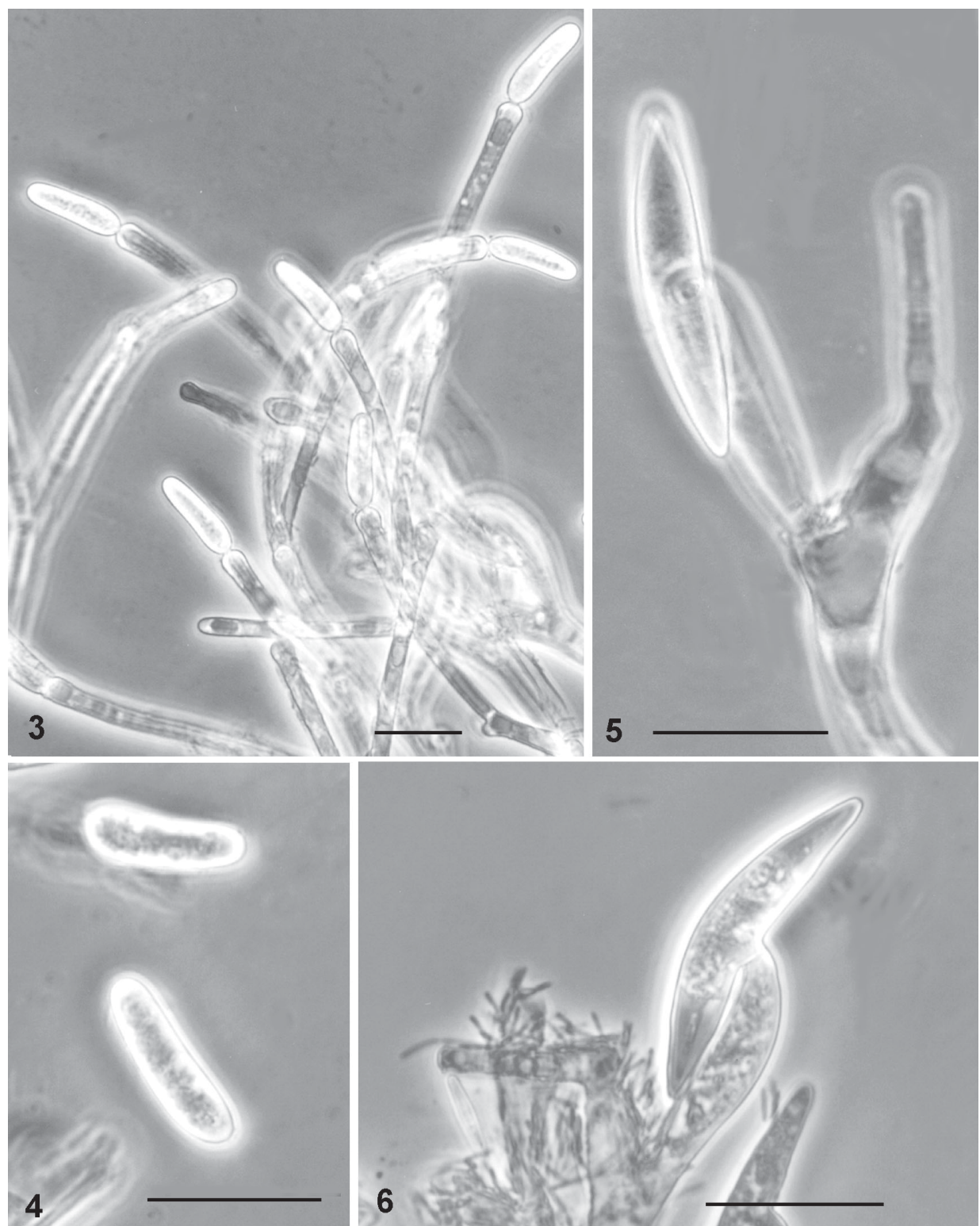

Figs 3-6: Genistellospora tropicalis. Fig. 3: attached trichospores. Fig. 4: detached trichospores. Figs 5, 6: zygospores. Scale bars $=25 \mu \mathrm{m}$
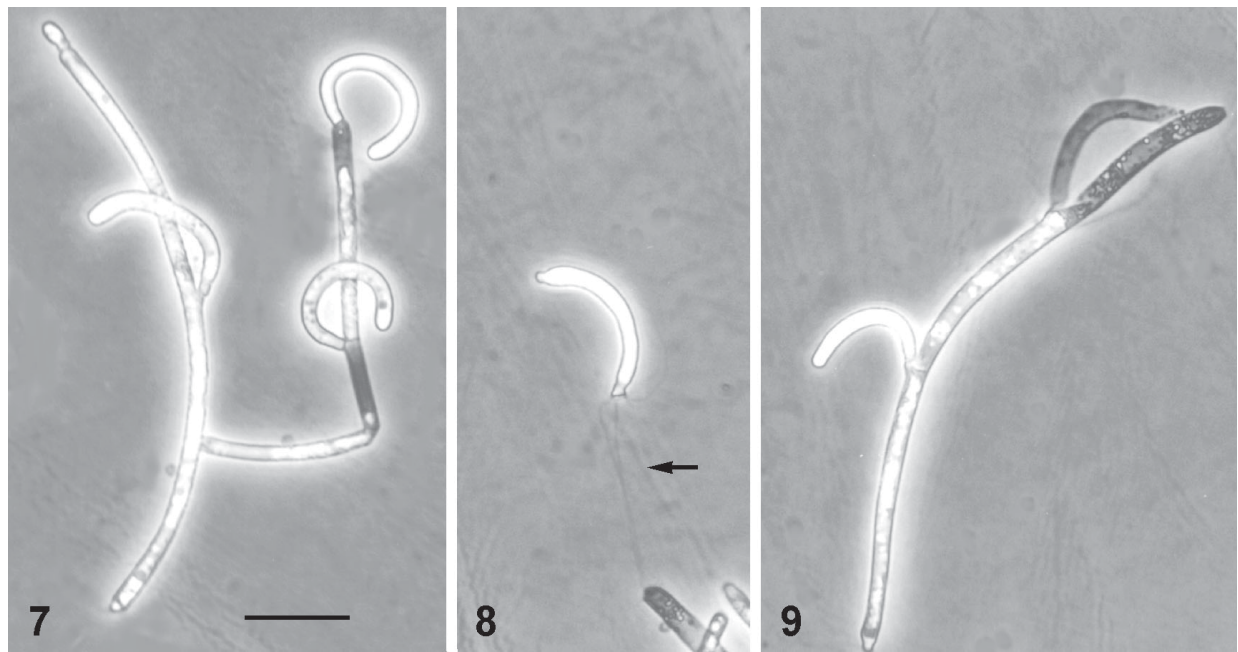

Figs 7-9: sporulating thalli of Harpella amazonica inside the peritrophic membrane of a Simuliidae larva, and one detached trichospore with multiple barely visible appendages (arrow pointing to one). Scale bar $=25 \mu \mathrm{m}$ for all figures 
Etymology: from Brazil.

Holotype: microscope slide BR-6-1, from which photographs A00 and A1, were made (show branched thalli, holdfast horseshoe shaped, released and attached trichospores and zygospores) prepared from a larva of $S$. goeldii (Diptera: Simuliidae) collected on 10-X-2000 from Igarapé Barro Branco (Site 2, Table).

Paratype: Simulium ulyssesi, S. goeldii and S. rorotaense larvae infected with $S$. brasiliense were found in streams at the Sites 1 and 10, Table. S. brasiliense was very common in the examined specimens.
From the species of Smittium currently described, $S$. brasiliense trichospores and the shape of zygospores most closely resemble those of Smittium dipterorum Lichtwardt, 1997, a species found within the hindgut of Simuliidae and Chironomidae larvae in Costa Rica (Lichtwardt 1997). However, in S. dipterorum zygospores are longer than in $S$. brasiliense. Another significant difference is the presence of a horseshoe shaped holdfast structure in $S$. brasiliense, whereas $S$. dipterorum's attachment to the cuticle is a by a simple secreted structure. In the Amazonas region, S. brasiliense was observed
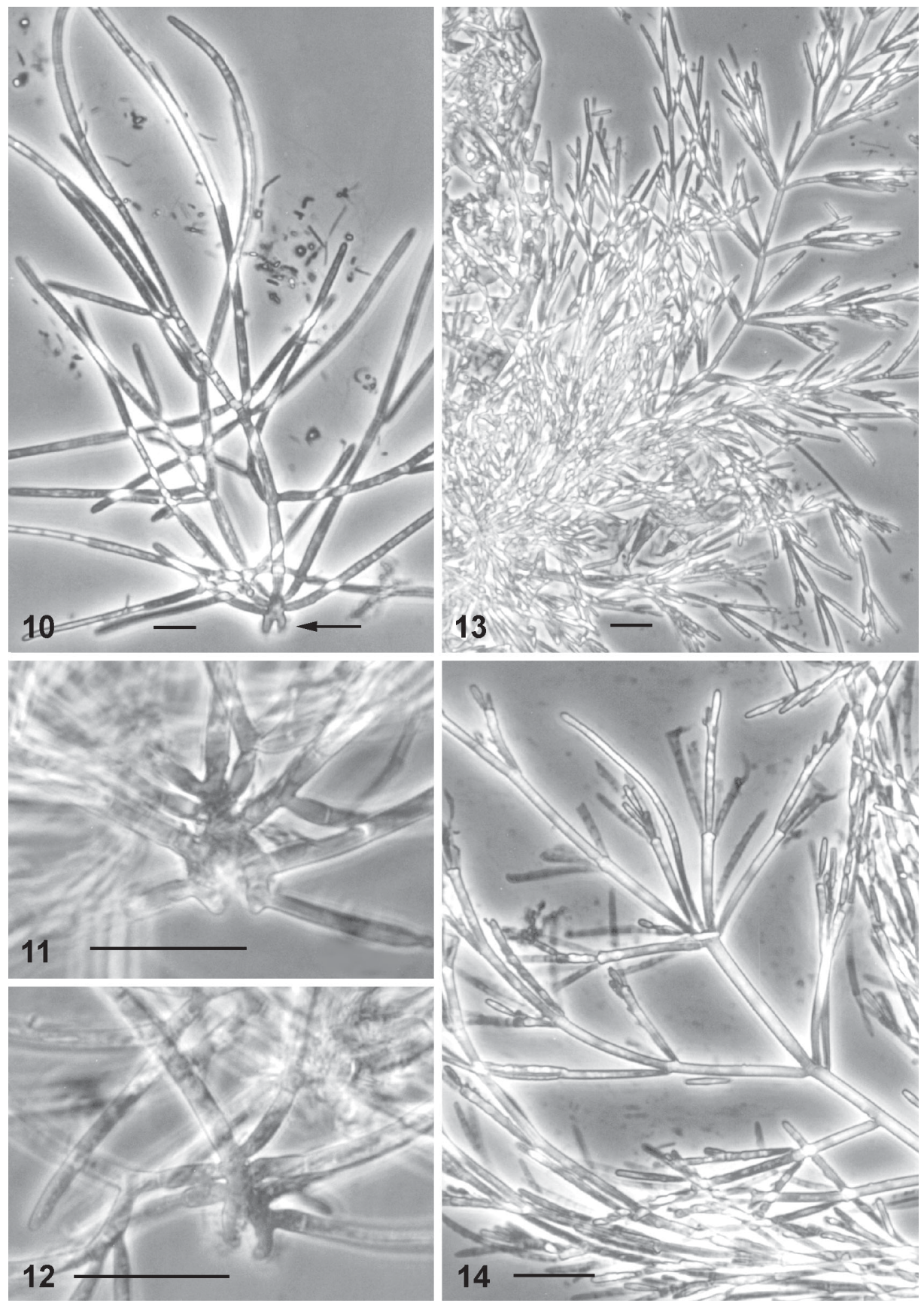

Figs 10-14: Smittium brasiliense from a Simuliidae larvae. Fig. 10: immature thallus with horseshoe-shaped basal cell (arrow) by which the thallus was attached to the hindgut cuticle. Figs 11, 12: basal cells of mature thalli. Fig 13: part of a dense thallus removed from a hindgut. Fig 14: verticillate branching typical of this species. Scale bars $=25 \mu \mathrm{m}$ 
sharing the same Simuliidae gut with Harpella and Genistellospora.

\section{Stachylina paucispora, sp. nov. Lichtwardt} (Figs 22-23)

Thallus fusiform $\sim 70-85 \times 6-7 \mu \mathrm{m}$. Long-ellipsoidal trichospores, 29-40 x 6-8 $\mu \mathrm{m}$ with a single appendage and without a collar. Two of the thalli are conjugating (this is very uncommon in Stachylina). One to two trichospores per thallus. In the hindgut of Orthocladiinae.

Diagnosis: thali fusiformes, $\sim 70-85 \times 6-7 \mu \mathrm{m}$. Trichosporae longi-ellipsoideae, $29-40 \times 6-8 \mu \mathrm{m}, 1-2$ per thallium. In proctodaeo larvarum Orthocladiinarum (Chironomidarum). Etymology: Latin paucus $=$ few, for the few spores produced per thallus.

Holotype: microscope slide BR-9-1, from which photographs B11-B12 were made (show thalli and trichospores) prepared from a larva of (Orthocladiinae, Cricotopus) (Diptera: Chironomidae) collected on 10-X2000 from a concrete ditch with running water near Paiol da Cultura, Inpa (Site 5, Table). This larva also had a nonsporulating Smittium in its hindgut.

Two of the thalli appeared to be conjugating (Figs 22, 23), which is very uncommon in Stachylina.
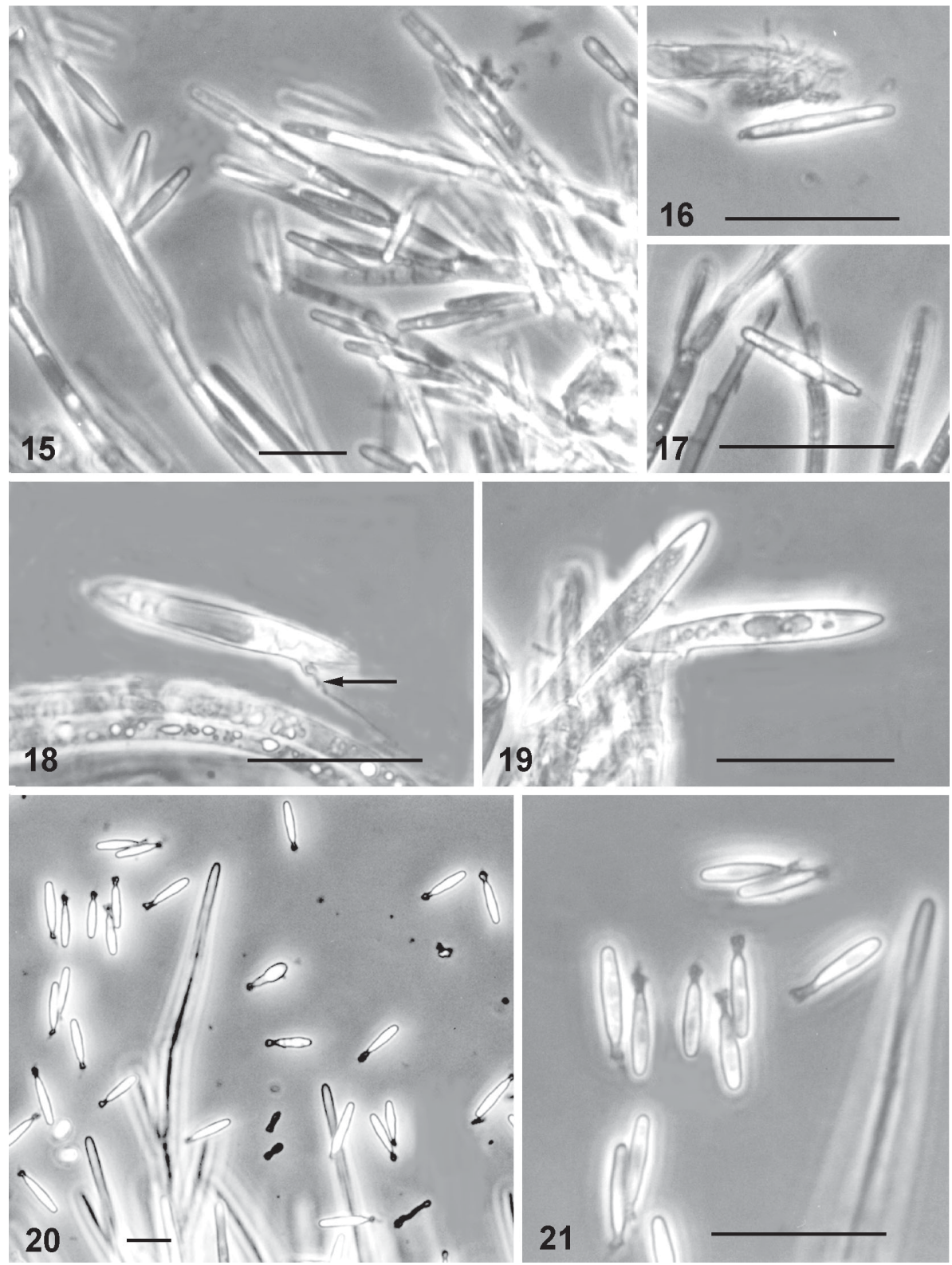

Figs 15-21: Smittium brasiliense. Fig. 15: sporulating branchlets. Figs 16, 17: released trichospores. Figs 18, 19: zygospores, one showing a single appendage (arrow) trailing from a small collar. Figs 20, 21: trichospores produced by thalli in an axenic culture of the fungus. Scale bars $=25 \mu \mathrm{m}$ 


\section{SPECIES WITH PUBLISHED NAMES}

Leidyomyces attenuatus (Leidy) Lichtwardt, White, Cafaro \& Misra, 1999

(Figs 22-23)

Leidyomyces attenuatus (Eccrinales) is found virtually throughout the range of Passalidae (Coleoptera) in the Americas (Lichtwardt et al. 1999b). The fungus was named by Leidy (1849b) as Enterobryus attenuatus, which he discovered in passalid beetles in Eastern United States. A more complete description of the fungus was provided by Lichtwardt (1957) under Leidy's original name. Subsequently, what appears to be the same morphological species, now renamed L. attenuatus, has been found in some Caribbean islands, Central America, and South America as far south as São Paulo, Brazil. The original collections in Brazil included four regions of the Amazon, one of which was Manaus (Lichtwardt et al. 1999b).

Thalli of L. attenuatus occur in the anterior part of the long passalid hindgut. The most anterior thalli commonly are grouped into clusters of unbranched thalli whose individual holdfasts are fused into one holdfast complex (Mayfield \& Lichtwardt 1980). This feature is illustrated on the web site. The range of hosts includes many genera and species of Passalidae. The fact that it has such a wide host range and geographic distribution suggests that $L$. attenuatus evolved in Passalidae at the time of their early radiations. In the Reserva Ducke (Site 1) we collected on 6-X-2000 several specimens of the large beetle, Passalus convexus Dalman, 1814, from partially rotted logs. Their guts contained both $L$. attenuatus and a second hindgut fungus, Passalomyces compressus, described below.

Passalomyces compressus (Thaxter) Lichtwardt, White, Cafaro \& Misra, 1999

(Figs 24, 25)

This unusual Eccrinales in Passalidae hindguts has been found only in tropical regions of the Americas. First named Enterobryus compressus by Thaxter (1920) from a passalid species collected in the Dominican Republic, it has now been found in Costa Rica, Panama, and Brazil (Macapá and Belém) and was renamed by Lichtwardt et al. (1999b). The unbranched thalli at maturity can project from the anus, and some are actually attached to the beetle's anal plates. Sporangiospores are flattened and allantoid in shape, and emerge from the side of the sporangium. Specimens of $P$. compressus came from the same passalid collection as $L$. attenuatus, above.

\section{Smittium aciculare Lichtwardt, 1990}

(Figs 26-28)

Smittium aciculare was described in Lichtwardt and Williams (1990) from collections of Austrosimulium mirabile Mackeras \& Mackeras and Simulium clathrinum
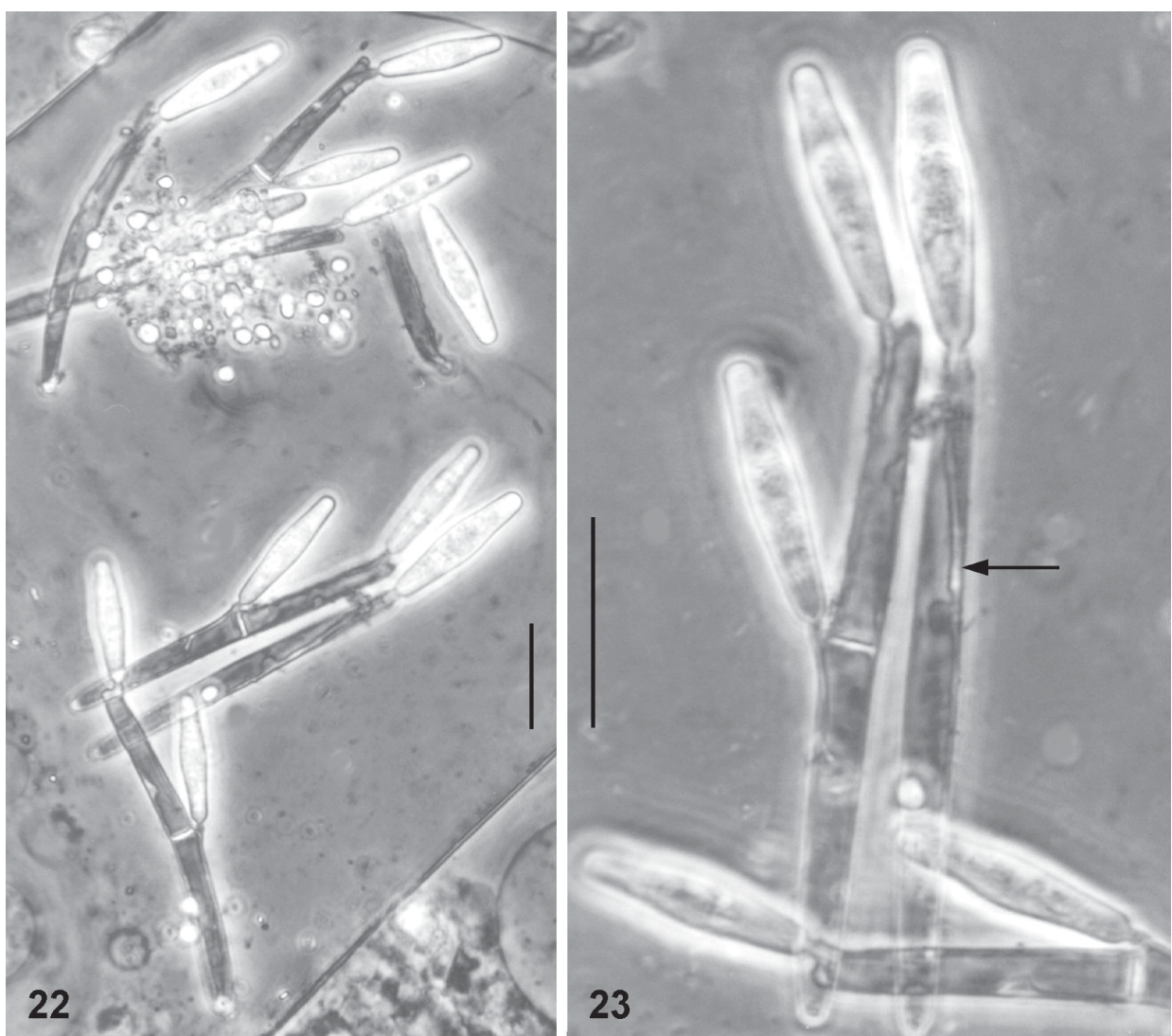

Figs 22, 23: Stachylina paucispora from a Chironomidae larva. Mature thalli within the peritrophic membrane, each producing one or two trichospores. Two sporulating thalli that appear to be conjugating; the arrow points to an appendage within the generative cell. Scale bars $=25 \mu \mathrm{m}$ 
Mackeras \& Mackeras (Simuliidae) in tropical Queensland, Australia. In Amazonas, we found what appears to be the same species in larvae of Simulium trombetense at Sites 7 and 8 collected 11-X-2000. The original description of this Harpellales stated that thalli were 150-350 $\mu \mathrm{m}$ long, acicular, sparsely branched or unbranched, and tapered at the base,

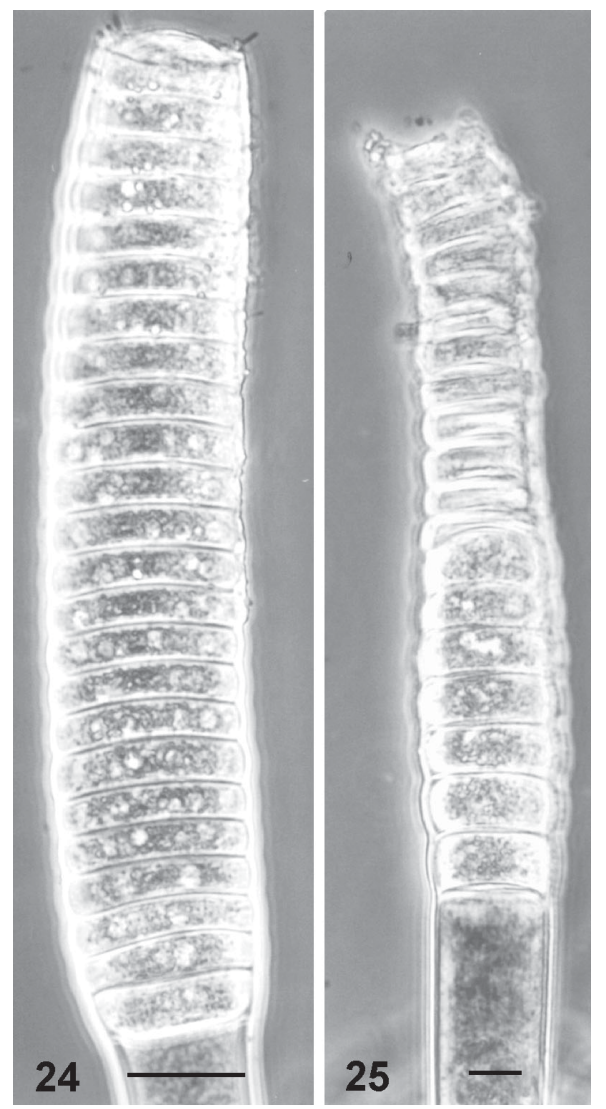

Figs 24, 25: sporulating tips of unbranched thalli of Passalomyces compressus (Eccrinales) that were projecting from the anus of a Passalidae beetle, consisting of flattened sporangia each bearing one sporangiospore. Scale bars $=25 \mu \mathrm{m}$ with long fusiform-ellipsoidal trichospores 28-30 x $3.4 \mu \mathrm{m}$. Our specimens had thalli that were unbranched, about $200 \mu \mathrm{m}$ long, and tapered at the base (Fig. 26), with trichospores $\sim 30-33 \times 3-3.5 \mu \mathrm{m}$, with a very short collar. Though the two sites are very disjunct, the fungi appear to be conspecific.

\section{Smittium culisetae Lichtwardt, 1964}

(Figs 29-32)

Smittium culisetae appears to have a worldwide distribution. It has been reported from Japan, Australia, New Zealand, Hawaii, continental US, France, Argentina, Costa Rica, and Brazil (Lichtwardt 1986, 1997, Lichtwardt et al. 1999a, Pereira et al. 2000). The most common host is mosquito larvae (Culicidae), but this Harpellales has an unusually wide host range that includes Simuliidae, Chironomidae, Ceratopogonidae and Tipulidae; in Australia it was once found in Ephemeroptera nymphs (Lichtwardt \& Williams 1990). The species is easily identified by its relatively small trichospores [(11)16(-30) x (3-)4(-7) $\mu \mathrm{m}]$ with a slight bulge below the middle (Figs 31,32) and a very short collar, and thalli with verticillate branching.

Cultures of $S$. culisetae from Amazonas were isolated from Culex sp. (Culicidae) larvae collected on 5-X-2000 at Centro Ecológico (Site 4).

\section{SPECIES ILLUSTRATED AND DESCRIBED, BUT NOT NAMED}

\section{Enterobryus sp.}

(Figs 33-35)

The hindguts of many species of millipedes (Diplopoda) throughout the world are hosts to Enterobryus (Eccrinales) (Lichtwardt 1986, and unpublished), the first genus of Trichomycetes to be named (Leidy 1849a). Identifying or providing new names for species of Enterobryus may require large numbers of host specimens with different stages of development and much study, because of the intraspecific variability exhibited by most species of this genus (Lichtwardt 1986). We report here
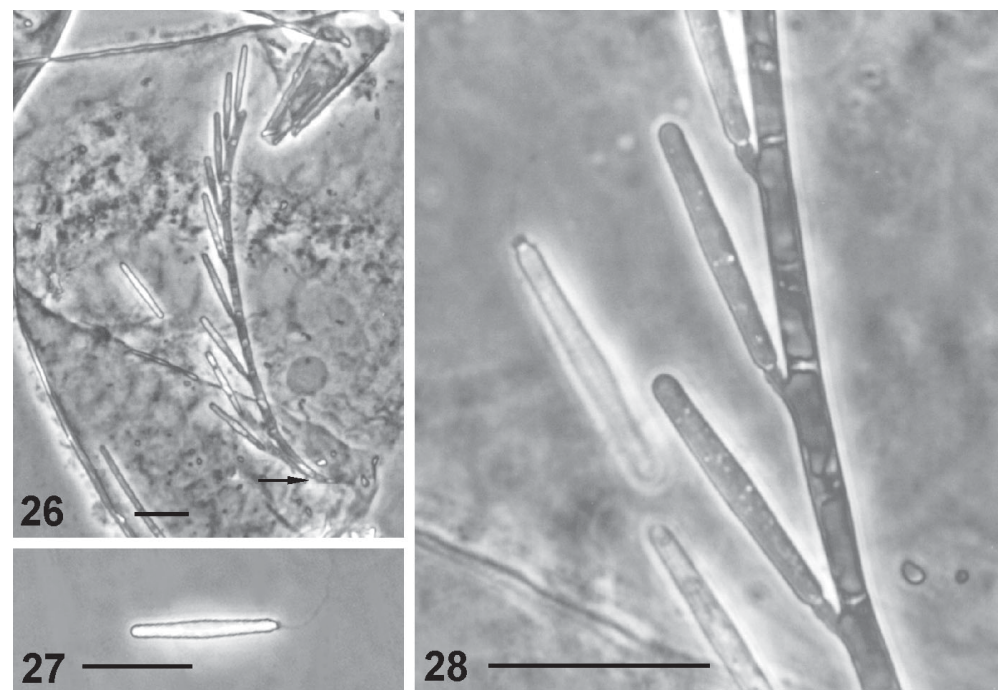

Figs 26-28: Smittium aciculare in the hindgut of a Simuliidae larva. Fig. 26: small, essentially unbranched, thallus with a tapered base (arrow). Fig. 27: released trichospore. Fig. 28: thallus with attached and detached trichospores. Scale bars $=25 \mu \mathrm{m}$ 
one species of Enterobryus that is probably new, which was found in a small spirobolid millipede on 16-X-2000 on the main Inpa campus (Site 6). The feature that makes this eccrinid unusual is the presence of extremely long holdfasts in mature thalli (Figs 33, 34). Holdfasts in Eccrinales attach thalli to the hindgut cuticle, and are extruded through pores in the wall at the base of the thalli (Mayfield \& Lichtwardt 1980). In some species, such as this one, the holdfast substance may continue to be extruded during growth and maturation of the thallus. We did not find sufficient numbers of sporulating thalli to permit an adequate description of this Enterobryus.

\section{Harpella sp. \\ (Fig. 36)}

In a larva of Simulium perflavum Roubaud (Simuliidae) collected 14-X-2000 from Igarapé do Km 4/ CIGS (Site 3) we found a species of Harpella that may be new, but it is not named at this time. It had very long thalli, up to 280-344 $\mu \mathrm{m}$ with a rounded holdfast of less diameter than the thallus. Trichospores were curved to coiled, (46-)50(-60) x 3-6 $\mu \mathrm{m}$. About 12 trichospores per tallus were present. The length of the thalli and narrowness of the trichospores do not match any other described species.
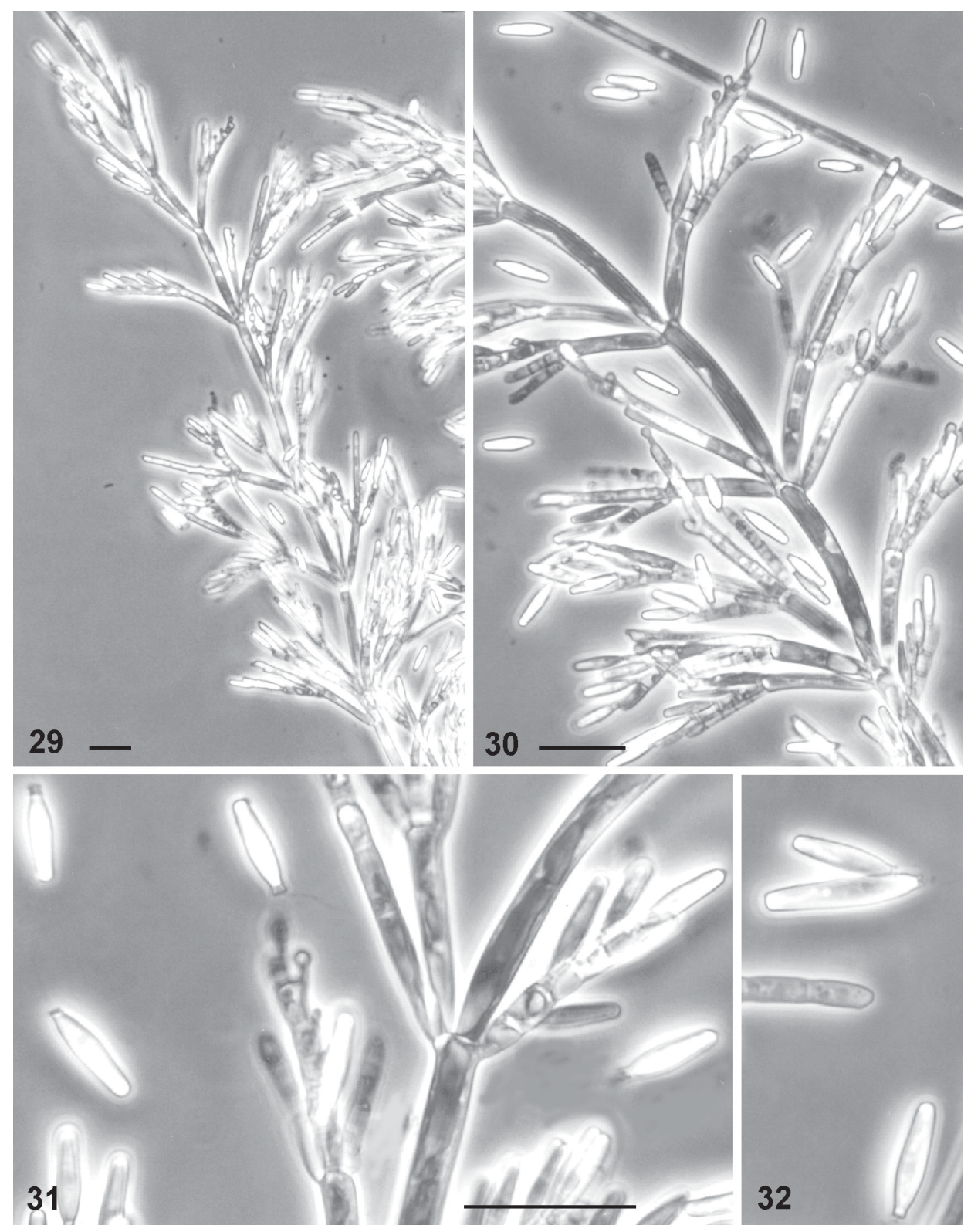

Figs 29-32: axenic culture of Smittium culisetae isolated from a mosquito larva. Figs 29, 30: sporulating branches with a verticillate branching pattern. Fig. 31: attached and loose trichospores. Fig. 32: detached trichospores showing size variation that is typical of this species. Scale bars $=25 \mu \mathrm{m}$; for Fig. 32 see bar of Fig. 31 


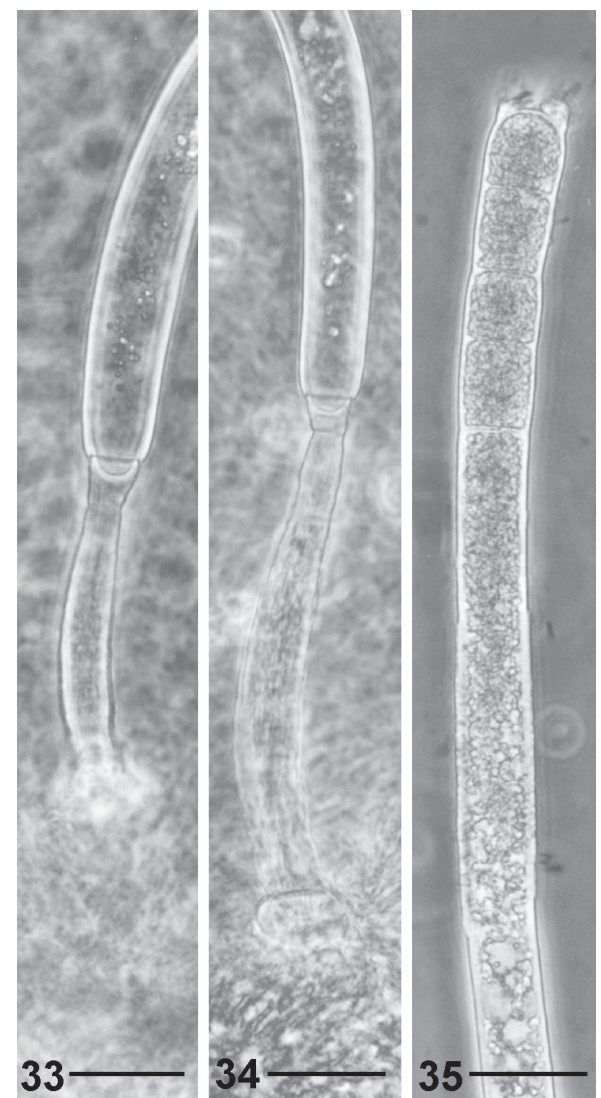

Figs 33-35: unbranched thalli of Enterobryus sp. (Eccrinales) growing in the hindgut of a millipede (Diplopoda), two showing extremely long secreted holdfasts and the tip of one thallus producing uninucleate sporangiospores. Scale bars $=25 \mu \mathrm{m}$

\section{Stachylina sp.}

(Figs 37, 38)

This undescribed species was attached to the peritrophic membrane of a Corynoneura sp. (Chironomidae: Orthocladiinae) larva collected 11-X-00 from Igarapé Canoas (Site 7). Sporulating thalli were about $110 \times 5.5 \mu \mathrm{m}$ with one or two long-ellipsoidal trichospores measuring about $32 \times 5 \mu \mathrm{m}$. Specimens were too few to provide a good description of the species, but the dimensions of the trichospores and the few number produced per thallus suggest the species is new.

\section{DISCUSSION}

Simuliidae are hosts to seven genera of Harpellales, three of which we report here with new species: $G$. tropicalis, $H$. amazonica, and S. brasiliense. Another fungus from Simuliidae, Simuliomyces microsporus, has been found on four continents, including the countries of Costa Rica, Argentina and Chile (Lichtwardt 1986, 1997, Lichtwardt \& Williams 1990, Lichtwardt \& Arenas 1996, Lichtwardt et al. 1999a), but has not yet been recorded from Brazil. Pennella is a relatively common genus in Simuliidae in the US and Canada, but only two species have been found farther south, in Costa Rica: P. simulii M.C. Williams \& Lichtw. and P. montana Lichtw. The latter species is also known to occur in Northwestern Argentina (Lichtwardt et al., 2000). Such distributions suggest that

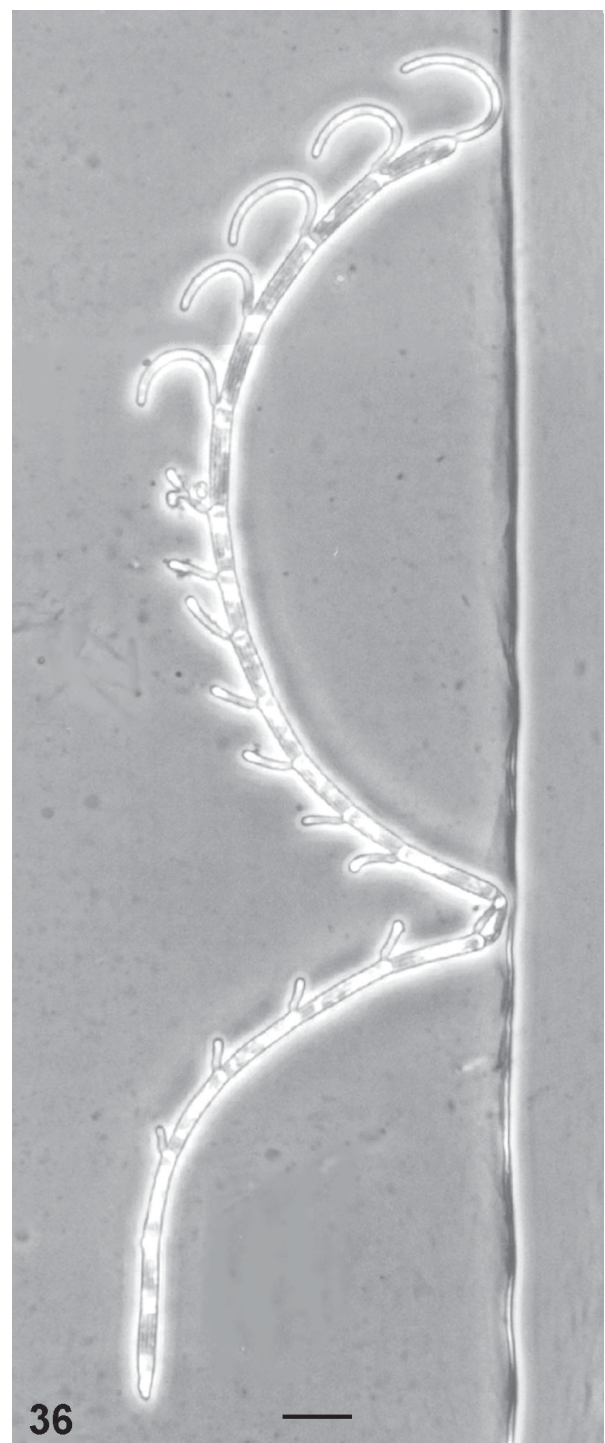

Fig. 36: a single thallus of Harpella sp., as seen within the peritrophic membrane of a Simuliidae larva, producing numerous curved trichospores at various stages of development (composite of two photomicrographs). Scale bar $=25 \mu \mathrm{m}$

there are other genera and almost certainly new species of Trichomycetes living in Simuliidae that are yet to be discovered in Brazil.

Chironomidae are also frequent hosts of Harpellales, with six recorded genera inhabiting their guts. They are hosts to most known species of Stachylina (23 of 26) and Smittium (49 of 56), though six Smittium spp. are found in both Chironomidae and Simuliidae. In our studies we emphasized Trichomycetes in Simuliidae, and only described one new species in Chironomidae, Stachylina paucispora. Undoubtedly, the Amazon region contains numerous Chironomidae that will prove to be hosts to Harpellales when additional specimens are sought.

None of the new species in this paper have been found in Costa Rica, the only tropical region of the Americas where intensive studies on Harpellales have been done 

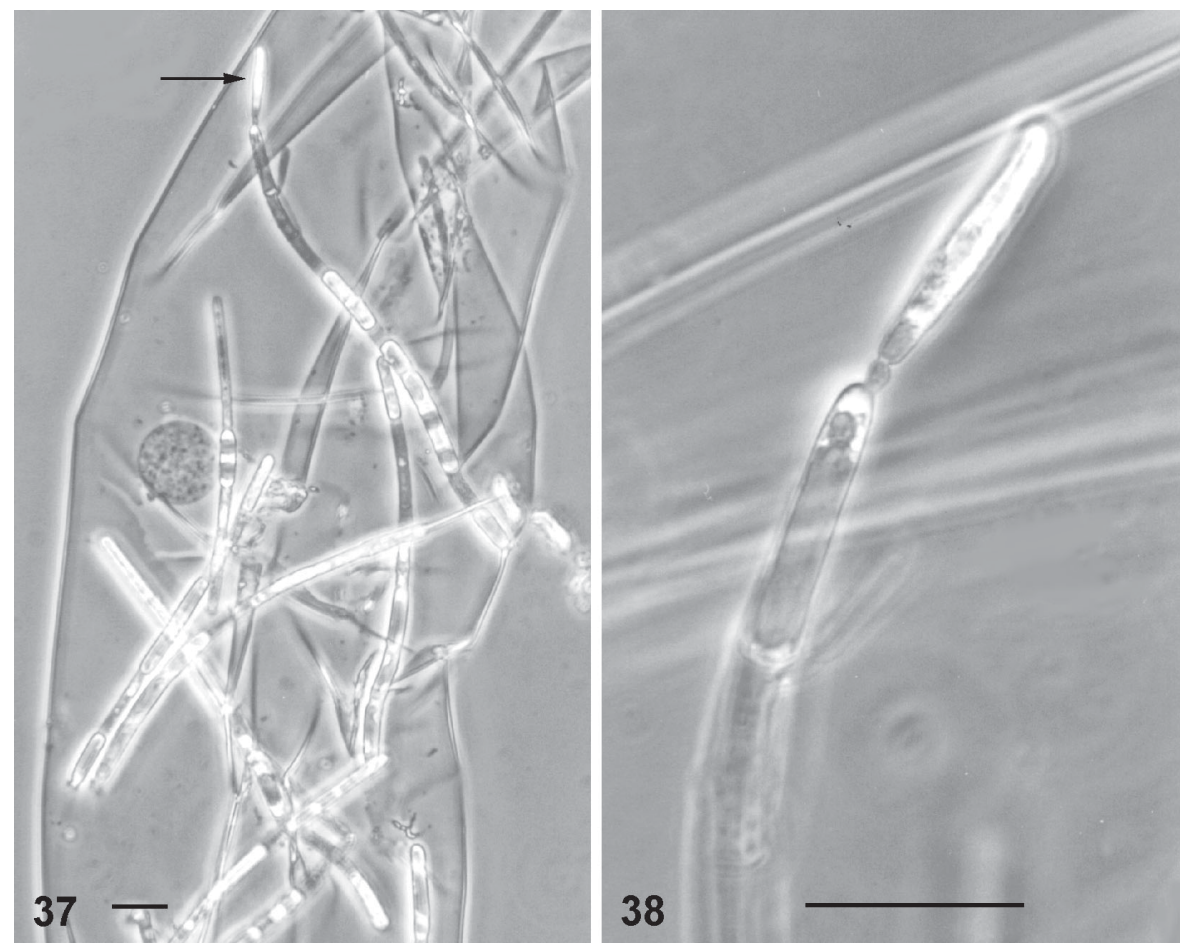

Figs 37, 38: unbranched thalli of Stachylina sp. within the peritrophic membrane of a minute Corynoneura sp. (Chironomidae) larva; one thallus has produced a single trichospore (arrow). Scale bars $=25 \mu \mathrm{m}$

(Lichtwardt 1994, 1997). S. aciculare from Amazonas appears to be the same species originally described from tropical Queensland, Australia. Such a disjunct distribution suggests that $S$. aciculare may exist in other regions of the world as well.

Of special interest is the biogeography of Harpella. H. melusinae is known from all areas of the Northern Hemisphere where Simuliidae have been collected and dissected, as well as in Australia and New Zealand, often occurring in a high percentage of larvae in almost all populations. Prior to the current study, investigation on Trichomycetes have been conducted in relatively few regions of the Americas, South of the US. With this in mind, it can be said that $H$. melusinae has not yet been found in Central or South America. Rather, H. meridianalis is the predominant and a very common species in Simuliidae in Southern Chile and Argentina (Lichtwardt \& Arenas 1996, Lichtwardt et al. 1999a, 2000). H. tica, which generally appears to prefer Simuliidae larvae inhabiting warmer stream waters, was found in over $95 \%$ of Simuliidae larvae in Costa Rica (in streams as cool as $11-17.5^{\circ} \mathrm{C}$ but mostly $19.5-28^{\circ} \mathrm{C}$ ) and subsequently was found in warm waters $\left(17-24.5^{\circ} \mathrm{C}\right)$ in northwestern provinces of Argentina (Lichtwardt et al. 1999a) and Puerto Rico $\left(22-25^{\circ} \mathrm{C}\right)$ (White et al. 2000). In the central Amazon region of Brazil, stream temperatures in the forest, tend to be constant, around $24^{\circ} \mathrm{C}$ throughout the year (Hamada \& Adler 2001).

Factors that determine whether or not dipteran larvae are infected with particular species of Harpellales can be attributed to many aspects in their aquatic habitats, such as temperature, organic matter, $\mathrm{pH}$, and dissolved minerals, and undoubtedly also to historical biogeography and host specificity, but these ecological aspects that relate fungal symbionts to their hosts are just beginning to be addressed. A summary of tropical Trichomycetes recorded, in the literature has been provided by White et al. (2000).

\section{ACKNOWLEDGMENTS}

To the National Science Foundation PEET, grant DEB9521811 and Inpa (PPI 1-3070) for partial support to R Lichtwardt. To Dr Claudio RF Vasconcelos and Dr José W Morais for the passalid and Diplopoda identifications, respectively; to MSc Arlindo Serpa Filho for the chironomid identifications and Jeferson Oliveira da Silva for technical support. To Dr Patricia M Eckel for translating the diagnoses into Latin. Dayse Queiróz made the map drawing.

\section{REFERENCES}

Benny GL, O’Donnell K 2000. Amoebidium parasiticum is a protozoan, not a Trichomycete. Mycologia 92: 1133-1137.

Hamada N, Adler PH 2001. Bionomia e chave para imaturos e adultos de Simulium (Diptera: Simuliidae) na Amazônia Central, Brasil. Acta Amazonica 31: 109-132.

Labeyrie ES, Molloy DP, Lichtwardt RW 1996. An investigation of Harpellales (Trichomycetes) in New York State blackflies (Diptera: Simuliidae). J Inv Path 68: 293-298.

Léger L, Duboscq O 1929. Harpella melusinae n.g.n. sp. Entophyte eccriniforme parasite des larves de Simulie. Comptes Rendus Hebdomadaires des Séances de l'Académie des Sciences Paris 188: 951-954.

Leidy J 1849a. Enterobryus, a new genus of Confervaceae. Proc Acad Nat Sci Philadelphia 4: 225-233.

Leidy J 1849b. Descriptions (accompanied by drawings,) of 
new genera and species of Entophyta. Proc Acad Nat Sci Philadelphia 4: 249-250.

Lichtwardt RW 1957. Enterobryus attenuatus from the Passalid beetle. Mycologia 49: 463-474.

Lichtwardt RW 1986. The Trichomycetes: Fungal Associates of Arthropods, Springer-Verlag, New York, 343 pp.

Lichtwardt RW 1994. Trichomycete fungi living in the guts of Costa Rican phytotelm larvae and other lentic dipterans. Rev Biol Trop 42: 31-48.

Lichtwardt RW 1996. Trichomycetes and the arthropod gut. In D Howard, D Miller (eds), The Mycota, Animal and Human Relations, Springer-Verlag, New York, p. 315-330.

Lichtwardt RW 1997. Costa Rican gut fungi (Trichomycetes) infecting lotic insect larvae. Rev Biol Trop 45: 1349-1383.

Lichtwardt RW, Arenas MJ 1996. Trichomycetes in aquatic insects from Southern Chile. Mycologia 88: 844-857.

Lichtwardt RW, Williams MC 1990. Trichomycete gut fungi in Australian aquatic larvae. Can J Bot 68: 1057-1074.

Lichtwardt RW, Cafaro MJ, White MM 2001. The Trichomycetes: fungal associates of arthropods. Revised edition. Published on the Internet: www.nhm.ku.edu/ fungi.

Lichtwardt RW, Ferrington Jr LC, López Lastra C 1999a. Trichomycetes in Argentinean aquatic insect larvae. Mycologia 91: 1060-1082.

Lichtwardt RW, López Lastra C, Mazzucchelli MG 2000. Fungi living in the guts of larval aquatic insects in Northwestern Argentina. Mycologia 92: 332-340.

Lichtwardt RW, White MM, Cafaro MJ, Misra JK 1999b. Fungi associated with passalid beetles and their mites. Mycologia
91: 604-702.

López Lastra C 1990. Primera cita de Smittium morbosum var. rioplatensis var. nov. (Trichomycetes: Harpellales) patógeno de cinco especies de mosquitos (Diptera: Culicidae) en la República de Argentina. Rev Arg Mic 13: 14-18.

Mayfield SD, Lichtwardt RW 1980. Comparative study of the holdfast structure in four Trichomycetes. Can J Bot 58: 1074-1087.

Misra JK 1998. Trichomycetes fungi associated with arthropods: Review and world literature. Symbiosis 24: 179-220.

Misra JK, Lichtwardt RW 2000. Illustrated Genera of Trichomycetes: Fungal Symbionts of Insects and Other Arthropods, Science Publishers, Inc., Enfield, New Hampshire, 155 pp.

Moss ST, Lichtwardt, RW 1980. Harpella leptosa, a new species of Trichomycetes substantiated by electron microscopy. Can J Bot 58: 1035-1044.

Pereira ES, Hamada N, Ferreira RLM 2000. Levantamento de larvas de mosquitos (Diptera: Culicidae) e fungos Trichomycetes associados em criadouros naturais e artificiais no município de Manaus, AM. Anais da IX Jornada de Iniciação Científica do Pibic/Inpa, Manaus, AM, p. 138142.

Thaxter R 1920. Second note on certain peculiar fungus-parasites of living insects. The Bot Gaz 69: 1-27.

White MM, Cafaro MJ, Lichtwardt RW 2000. Arthropod gut fungi from Puerto Rico and summary of tropical Trichomycetes worldwide. Caribbean J Sci 36: 210-220. 